\title{
Distribution of small- and medium-sized molecules within the genital tract of artificially inseminated gilts
}

\author{
S. Einarsson, B. Jones*, K. Larsson and S. Viring \\ Department of Obstetrics and Gynaecology and *Department of Clinical Chemistry, Faculty of \\ Veterinary Medicine, The Swedish University of Agricultural Sciences, S-750 07 Uppsala 7, \\ Sweden
}

\begin{abstract}
Summary. Radiolabelled compounds of different molecular size were used as tracers mixed with seminal plasma to investigate whether seminal plasma enters the oviducts of inseminated gilts. The substances were ${ }^{125}$ I-labelled human serum albumin for 3 gilts, ${ }^{131} \mathrm{I}$-labelled polyvinylpyrrolidone plus ${ }^{59} \mathrm{Fe}$ citrate in 2 gilts and ${ }^{131} \mathrm{I}$-labelled human serum albumin plus ${ }^{59} \mathrm{Fe}$ citrate in 2 gilts. The gilts were slaughtered $1 \mathrm{~h}$ after insemination and the radioactivity was measured in 4 parts of the oviduct, 9 parts of the uterine horns, the body of the uterus and the cervix. Different quantities of the compounds used were found in all oviducts, but there was close agreement between the distributions of the two compounds in the genital tract after simultaneous insemination. There was a difference $(60-80 \%)$ in total amount of recovered radioactivity between left and right uterine horns. It is concluded that all compounds used entered the oviducts regardless of their molecular sizes.
\end{abstract}

\section{Introduction}

Spermatozoa are rapidly transported along the uterus and enter the oviducts shortly after natural or artificial insemination in the oestrous pig (Burger, 1952; First, Short, Peters \& Stratman, 1968; Baker \& Degen, 1972; Hunter \& Hall, 1974). In other species non-cellular particles such as India ink and radio-opaque substances have been demonstrated to pass into the oviducts (cow: Rowson, 1955; rabbit: Inkster, 1964; man: De Boer, 1972). In contrast, Asch, Balmaceda \& Pauerstein (1977) did not recover significant amounts of radioactivity from the uterus or oviducts of rabbits after vaginal insemination of a mixture of labelled seminal plasma and unlabelled spermatozoa.

In the pig, Mann, Polge \& Rowson (1956) were unable to detect biochemically ergothioneine, fructose or citric acid in oviduct flushings from 2 gilts within $1 \mathrm{~h}$ after mating, and Polge (1978) could not demonstrate radio-opaque fluid within the oviducts at various times after insemination. There is considerable evidence that seminal plasma does not enter the oviducts of oestrous pigs in significant amounts after mating (see Hunter, 1975).

Since the biochemical methods used by Mann et al. (1956) were probably not sensitive enough to detect low concentrations of seminal plasma constituents, we have used radiolabelled compounds to study the movement of different-sized molecules into the oviducts of oestrous pigs. 


\section{Materials and Methods}

The 7 crossbred gilts (Swedish Landrace and Swedish Yorkshire breed) used were checked daily for oestrus with the aid of a vasectomized boar. The gilts were not used in these experiments until $24 \mathrm{~h}$ after the onset of their second or third oestrus.

All gilts were inseminated with $70 \mathrm{ml}$ seminal plasma mixed with $2-4 \mathrm{ml} 0.9 \%(\mathrm{w} / \mathrm{v}) \mathrm{NaCl}$ containing one or two labelled compounds of different molecular size (Table 1). The insemination was performed using a rubber catheter (Melrose \& O'Hagan, 1961). The seminal plasma utilized was sperm-free and was collected from a boar with testicular hypoplasia or from a vasectomized boar. The backflow of fluid through the vulva during and immediately after insemination was negligible.

Table 1. Specification of the radioactive substances added to seminal plasma and inseminated into oestrous gilts

\begin{tabular}{|c|c|c|c|c|}
\hline Gilt & Additive & Mol. wt & $\begin{array}{c}\text { Sp. act. } \\
(\mu \mathrm{Ci} / \mathrm{mg})\end{array}$ & $\begin{array}{c}\text { Amount } \\
\text { inseminated } \\
(\mu \mathrm{Ci})\end{array}$ \\
\hline 1 & $\begin{array}{l}{ }^{125} \text { I-Labelled } \\
\text { human serum } \\
\text { albumin* }\end{array}$ & 69000 & 100 & 200 \\
\hline $\begin{array}{l}2 \text { and } \\
3\end{array}$ & $\begin{array}{l}{ }^{125} \text { I-Labelled } \\
\text { human serum } \\
\text { albumin* }\end{array}$ & 69000 & $100-150$ & 450 \\
\hline \multirow[t]{2}{*}{$\begin{array}{l}4 \text { and } \\
5\end{array}$} & $\begin{array}{l}\text { 131I-Labelled } \\
\text { polyvinyl } \\
\text { pyrrolidone* }\end{array}$ & $\begin{array}{l}30000- \\
40000\end{array}$ & $20-60$ & 450 \\
\hline & ${ }^{39} \mathrm{Fe}$ citrate $\dagger$ & 335 & $\begin{array}{l}3000 \\
30000\end{array}$ & 450 \\
\hline \multirow[t]{2}{*}{$\begin{array}{l}6 \text { and } \\
7\end{array}$} & $\begin{array}{l}{ }^{131} \text { I-Labelled } \\
\text { human serum } \\
\text { albumin* }\end{array}$ & 69000 & $100-150$ & 400 \\
\hline & ${ }^{59} \mathrm{Fe}$ citrate $\dagger$ & 335 & $\begin{array}{l}3000 \\
30000\end{array}$ & 400 \\
\hline
\end{tabular}

* Supplied by AB Atomenergi Isotopservice Studsvik, Nyköping, Sweden.

$\dagger$ Supplied by the Radiochemical Centre, Amersham, England.

The gilts were slaughtered $1 \mathrm{~h}$ after insemination and the reproductive tracts were removed within $5 \mathrm{~min}$ after stunning and bleeding. Oviducts, uterine horns, uterine body and cervix were separated. Clamps were placed in position to divide each oviduct into 4 equal parts and each uterine horn into 9 parts. The oviduct segments were handled before the uterine segments and were numbered I (anterior) to IV (posterior segment). The anterior uterine segment, including the uterine part of the uterotubal junction, was $5 \mathrm{~cm}$ while the rest of the uterus was divided into 8 parts of equal length, 4 representing the middle and 4 the posterior part of the uterus. The uterine body and the cervix of each tract were also clamped and cut separately. Each segment of the tract was placed in a separate plastic container and measured for radioactivity.

The radioactivity of the oviducts was measured in a well-type two-channel gamma-counter (Nuclear Chicago Mark II). The uterine parts and the cervices were measured on top of a 4-inch NaI (T1) crystal using a 127-channel gamma-spectrometer (Nuclear Data Series One-Thirty 512 Channel Analyzer Computer). Standards were prepared for the two counting systems as dilutions of the isotope preparations used. The standard solutions were kept in plastic tubes similar in shape to the uterine samples. 


\section{Results}

The amounts of radioactivity recovered from 6 of the gilts varied from 17.6 to $71.2 \%$, but was very high (152\%) in Gilt 3. Samples of blood and blood plasma from Gilt 1 were measured in the same way as the oviduct samples but there was no detectable radioactivity.

The distribution patterns of radioactivity in the reproductive tracts are shown in Tables $2-4$. The recoveries from the oviducts of the different substances used varied between animals but the distribution of activity was relatively equal for the different segments of the oviducts except for Gilt 2 in which the activity of segment IV in the right oviduct was considerably higher than that in the other segments of either oviduct. Values for both radioactive compounds in all segments of the right oviduct of Gilt 4 were higher than those in the left.

Table 2. Single and median values of the amounts of ${ }^{125} \mathrm{I}$-labelled human serum albumin recovered from Gilts $1-3$, expressed as the percentage of the total radioactivity recovered in segments I-IV of the oviduct and in different parts of the uterus

\begin{tabular}{|c|c|c|c|c|c|c|c|}
\hline & \multicolumn{2}{|c|}{ Gilt 1} & \multicolumn{2}{|c|}{ Gilt 2} & \multicolumn{2}{|c|}{ Gilt 3} & \multirow{2}{*}{$\begin{array}{c}\text { Median } \\
\text { value }\end{array}$} \\
\hline & Left & Right & Left & Right & Left & Right & \\
\hline \multicolumn{8}{|l|}{ Oviduct $\left(\times 10^{-3}\right)$} \\
\hline & 0.01 & 0.01 & 0.01 & 0.19 & 0.03 & 0.05 & 0.02 \\
\hline II & 0.01 & 0.01 & 0.01 & 0.13 & 0.03 & 0.06 & 0.02 \\
\hline III & 0.004 & 0.002 & 0.01 & 0.10 & 0.02 & 0.04 & 0.02 \\
\hline IV & 0.01 & 0.01 & 0.01 & 1.4 & 0.03 & 0.04 & 0.02 \\
\hline Median value & 0.01 & 0.01 & 0.01 & 0.16 & 0.03 & 0.05 & \\
\hline \multicolumn{8}{|l|}{ Uterine horn } \\
\hline Anterior & 15 & 0.04 & 0.1 & 4 & 0 & 10 & $2 \cdot 2$ \\
\hline Middle & 61 & 6 & 3 & 20 & 1 & 45 & 13 \\
\hline Posterior & 3 & 13 & 11 & 61 & 15 & 28 & 14 \\
\hline Uterine body & \multicolumn{2}{|c|}{0.2} & \multicolumn{2}{|c|}{0.4} & \multicolumn{2}{|c|}{0.1} & 0.2 \\
\hline Cervix & \multicolumn{2}{|c|}{1} & \multicolumn{2}{|c|}{0.5} & \multicolumn{2}{|c|}{0.6} & 0.6 \\
\hline
\end{tabular}

Table 3. Single and median values of the amounts of ${ }^{131} \mathrm{I}$-labelled polyvinylpyrrolidone $\left({ }^{131} \mathrm{I}\right)$ and ${ }^{99} \mathrm{Fe}$ citrate $\left({ }^{59} \mathrm{Fe}\right)$ recovered from Gilts 4 and 5 , expressed as the percentage of the total radioactivity recovered from the tract

\begin{tabular}{|c|c|c|c|c|c|c|c|c|c|c|}
\hline & \multicolumn{4}{|c|}{ Gilt 4} & \multicolumn{4}{|c|}{ Gilt 5} & \multirow{2}{*}{\multicolumn{2}{|c|}{$\begin{array}{c}\text { Median } \\
\text { values }\end{array}$}} \\
\hline & \multicolumn{2}{|c|}{ Left } & \multicolumn{2}{|c|}{ Right } & \multicolumn{2}{|c|}{ Left } & \multicolumn{2}{|c|}{ Right } & & \\
\hline & ${ }^{131} \mathbf{I}$ & ${ }^{39} \mathrm{Fe}$ & ${ }^{131} \mathbf{I}$ & ${ }^{39} \mathrm{Fe}$ & ${ }^{131} \mathbf{I}$ & ${ }^{59} \mathrm{Fe}$ & ${ }^{131 !}$ & ${ }^{39} \mathrm{Fe}$ & ${ }^{131} \mathbf{I}$ & ${ }^{59} \mathrm{Fe}$ \\
\hline \multicolumn{11}{|l|}{ Oviduct $\left(\times 10^{-3}\right)$} \\
\hline I & 0.1 & 1 & 55 & 100 & 12 & 14 & 8 & 11 & 10 & 13 \\
\hline II & 0.1 & 0.6 & 34 & 75 & 7 & 8 & 7 & 10 & 7 & 9 \\
\hline III & 0.1 & 0.4 & 28 & 52 & 6 & 10 & 8 & 10 & 7 & 10 \\
\hline IV & 0.1 & 0.4 & 25 & 44 & 4 & 5 & 6 & 8 & 5 & 7 \\
\hline Median value & 0.1 & 0.5 & 31 & 64 & 7 & 9 & 8 & 10 & & \\
\hline \multicolumn{11}{|l|}{ Uterine horn } \\
\hline Anterior & 2 & 2 & 2 & 2 & 0.5 & 0.4 & 5 & 5 & 2 & 2 \\
\hline Middle & 40 & 39 & 28 & 29 & 12 & 12 & 32 & 33 & 30 & 31 \\
\hline Posterior & 17 & 17 & 9 & 10 & 8 & 8 & 40 & 39 & 13 & 14 \\
\hline Uterine body & & 1 & 1 & & & 1 & 1 & & 1 & 1 \\
\hline Cervix & & 1 & 1 & & & 1 & 1 & & 1 & 1 \\
\hline
\end{tabular}


Table 4. Single and median values of the amounts of ${ }^{131} \mathrm{I}$-labelled human serum albumin $\left({ }^{131} \mathrm{I}\right)$ and ${ }^{59} \mathrm{Fe}$ citrate $\left({ }^{59} \mathrm{Fe}\right)$ recovered from Gilts 6 and 7 , expressed as the percentage of total radioactivity recovered from the tract

\begin{tabular}{|c|c|c|c|c|c|c|c|c|c|c|}
\hline & \multicolumn{4}{|c|}{ Gilt 6} & \multicolumn{4}{|c|}{ Gilt 7} & \multirow{2}{*}{\multicolumn{2}{|c|}{$\begin{array}{l}\text { Median } \\
\text { values }\end{array}$}} \\
\hline & \multicolumn{2}{|c|}{ Left } & \multicolumn{2}{|c|}{ Right } & \multicolumn{2}{|c|}{ Left } & \multicolumn{2}{|c|}{ Right } & & \\
\hline & ${ }^{131} \mathrm{I}$ & ${ }^{59} \mathrm{Fe}$ & ${ }^{131} \mathrm{I}$ & ${ }^{39} \mathrm{Fe}$ & ${ }^{131} \mathbf{I}$ & ${ }^{59} \mathrm{Fe}$ & ${ }^{131} \mathbf{I}$ & ${ }^{39} \mathrm{Fe}$ & ${ }^{131} I$ & ${ }^{59} \mathrm{Fe}$ \\
\hline \multirow{2}{*}{\multicolumn{11}{|c|}{ Oviduct $\left(\times 10^{-3}\right)$}} \\
\hline & & & & & & & & & & 2 \\
\hline II & 0 & 0.03 & 0.04 & 0.02 & 4 & 3 & 4 & 4 & 2 & 2 \\
\hline III & 0 & 0.04 & 0 & 0.02 & 6 & 7 & 2 & 3 & 1 & 2 \\
\hline IV & 0.3 & 0.5 & 0 & 0.03 & 4 & 4 & 3 & 3 & 2 & 2 \\
\hline Median values & 0.1 & 0.12 & 0.02 & 0.03 & 4 & 4 & 4 & 4 & & \\
\hline \multicolumn{11}{|l|}{ Uterine horn } \\
\hline Anterior & 0.6 & 0.5 & 0.04 & 0.04 & 0.2 & 0.4 & 0.03 & 0.02 & 0.12 & 0.22 \\
\hline Middle & 35 & 37 & 9 & 7 & 17 & 16 & 2 & 2 & 13 & 12 \\
\hline Posterior & 42 & 42 & 13 & 11 & 56 & 59 & 21 & 19 & 32 & 31 \\
\hline Uterine body & & 0.4 & 0.5 & & & 1 & 2 & & 1 & 1 \\
\hline Cervix & & 0.8 & 0.7 & & & 3 & 2 & & 1 & 2 \\
\hline
\end{tabular}

After simultaneous insemination of two different compounds (Tables 3 and 4) there was close agreement between the distributions of the two compounds in the genital tract, as judged by recovered activity.

There was a great difference in results for left and right uterine horns and $60-80 \%$ of the recovered activity was found in one of the uterine horns, the left for Gilts $1,4,6$ and 7 and the right horn for Gilts 2, 3 and 5.

\section{Discussion}

The amounts of radiolabelled compounds recovered varied between gilts in the present investigation. The main part of the inseminate normally disappears from the uterus shortly after insemination (see du Mesnil du Buisson \& Dauzier, 1955; Rigby, 1964; First et al., 1968). However, great differences in rate of disappearance exist between individual gilts (Rigby, 1964). The large number of segments measured in each animal, and especially differences in conformation between standard and uterine segments during measurement account for the major part of the differences in recovery between gilts in the present study. The better uniformity of shape during the measurements in the well-type detector gave the values for the small oviduct segment greater accuracy.

The technique used showed that all the compounds did enter the oviducts and it is therefore probable that not only the labelled substances but also the seminal plasma in which they were mixed passed into the oviducts. Using a similar technique, Viring, Einarsson, Jones \& Larsson (1980) demonstrated that radiolabelled substances deposited in the uterine lumen reached the upper part of the oviducts within 5 min. This is in disagreement with the results of Mann et al. (1956) and Polge (1978) for pigs but similar to those for cows (Rowson, 1955).

The uterotubal junction constitutes a barrier regulating the passage of spermatozoa into the oviducts, and may also exert some selective action. However, dead spermatozoa are transported through the uterotubal junction of sows (First et al., 1968; Baker \& Degen, 1972) and Baker, Dziuk \& Norton (1968) supposed the underlying mechanism for this to be that dead and live spermatozoa are forced into the oviducts by uterine contractions. Viring \& Einarsson (1980) 
showed a relaxation of the isthmus close to the uterotubal junction in the presence of seminal plasma, thus facilitating the passage of spermatozoa into the oviducts.

Krzanowska (1974) has demonstrated that the mouse uterotubal junction acts as a barrier against morphologically abnormal spermatozoa, but the selective action was incomplete. Similar studies have not been reported in pigs. In the present study all compounds inseminated, mixed with seminal plasma, entered the oviducts regardless of their molecular sizes and no evidence for a selective action of the uterotubal junction was demonstrated.

A disproportionate distribution was demonstrated between left and right uterine horns in the amount of recovered radioactivity. This was not reflected in similar differences between oviducts. Rigby (1964) also found differences in the numbers of spermatozoa in left and right uterine horns in pigs but First et al. (1968) were unable to demonstrate any consistent difference. So far no reason for such a difference in distribution of the inseminate is known (see Viring et al., 1980).

This work was supported by grants from the Swedish Council for Forestry and Agricultural Research.

\section{References}

Asch, R.H., Balmaceda, J. \& Pauerstein, C.J. (1977) Failure of seminal plasma to enter the uterus and oviducts of the rabbit following artificial insemination. Fert. Steril. 28, 671-673.

Baker, R.D. \& Degen, A.A. (1972) Transport of live and dead boar spermatozoa within the reproductive tract of gilts. J. Reprod. Fert. 28, 369-376.

Baker, R.D., Dziuk, P.J. \& Norton, H.W. (1968) Effect of volume of semen, number of sperm and drugs on transport of sperm in artificially inseminated gilts. $J$. Anim. Sci. 27, 88-93.

Burger, J.F. (1952) Sex physiology of pigs. Onderstepoort J. vet. Res., Suppl. 2.

De Boer, C.H. (1972) Transport of particulate matter through the human female genital tract. J. Reprod. Fert. 28, 295-297.

du Mesnil du Buisson, F. \& Dauzier, L. (1955) Distribution et résorption du sperme dans la tractus génital de la truie: survie des spermatozoides. Annls Endocr. 16, 413-422.

First, N.L., Short, R.E., Peters, J.B. \& Stratman, F.W. (1968) Transport and loss of boar spermatozoa in the reproductive tract of the sow. J. Anim. Sci. 27, 1037-1040.

Hunter, R.H.F. (1975) Physiological aspects of sperm transport in the domestic pig, Sus scrofa. I. Semen deposition and cell transport. Br. vet. J. 131, 565-573.

Hunter, R.H.F. \& Hall, J.P. (1974) Capacitation of boar spermatozoa: The influence of post-coital separation of the uterus and the Fallopian tube. Anat. Rec. 180, 597-604.

Inkster, I.J. (1964) Sperm transport in the female rabbit. Proc. N.Z. Soc. Anim. Prod. 24, 67-68.

Krzanowska, H. (1974) The passage of abnormal spermatozoa through the uterotubal junction of the mouse. J. Reprod. Fert. 38, 81-90.

Mann, T., Polge, C. \& Rowson, L.E.A. (1956) Participation of seminal plasma during the passage of spermatozoa in the female reproductive tract of the pig and horse. J. Endocr. 13, 133-140.

Melrose, D.R. \& O'Hagan, C. (1961) Investigations into the techniques of insemination in the pig. Proc. 4 th Int. Congr. Anim. Reprod. \& A.I., The Hague, pp. 855-859.

Polge, C. (1978) Fertilization in the pig and horse. $J$. Reprod. Fert. 54, 461-470.

Rigby, J.P. (1964) The fate of spermatozoa in the genital tract of the sow following artificial insemination. Proc. 5th Int. Congr. Anim. Reprod. \& A.I., Trento, pp. 421-425.

Rowson, L.E.A. (1955) The movement of radio opaque material in the bovine uterine tract. Br. vet. J. 111 , 334-342.

Viring, S. \& Einarsson, S. (1980) Effect of boar seminal plasma on uterine and oviductal motility in oestrous gilts. Acta vet scand. (in press)

Viring, S., Einarsson, S., Jones, B. \& Larsson, K. (1980) Transuterine transport of small- and medium-sized molecules deposited in the uterus in gilts. J. Reprod. Fert. 59, 459-462. 